\title{
La Transrealidad del Objeto Poético
}

- Ia aparencialidad significativa del objeto poético, consiste en que éste puede ser tuna mera apariencia, una simple imagen; en otras palabras, en que posec una cierta independencia respecto de lo real -entendiéndose esta palabra "real" en el sentido linitado de realidad material o más propiamente histórica. Asi, por ejemplo, el calanllero Amadís de Gaula es poético, como son poéticos los personajes de los cuenios de Andersen. Ninguna de estas figuraciones corresponde a la realiclad histórica. Ni Amadís de Gatula ni los personajes ni las acciones de los cuentos de Andersen han existido en ningún lugar del espacio ni en ninguná época del tiempo. Son fantasias, creaciones inaginativas, apariencias. Sueños, dirían los románticos alemanes.

A esta condición de aparencialidad significativa la llamamos transrcalidad. para indicar que el objeto poético no es necesariamente irreal, que puede ser en sí mismo realcomo un paisaje o como una escena de lá vida coticliana pero que su caliclad poćtica no reside en su realidad sino en su apariencia significativa. Si en ma aparición tomamos ínicamente el significado, hacemos obra de lógica, de metafisica o cle ciencia; si, por el contrario, tomamos la mera apariencia sensible sin alusión al significado, podemos experimentar un placer o un dolor sensoriales, pero no un sentimiento poético. La poesía es un sentimiento del alma, y todo sen- 
timiento del alma tiene un sentido, es decir un objeto que está más allá del mero sentir. Y bien, esta calidad del aparecer que trasciende así la realidad como la irrealidad del objeto poético es la transrealidad. En ella el objeto adquiere su plena autononia estética, su absoluta incondlicionalidad. Ya no depencic de ninguna contingencia material. Se levanta por encina de su mera realidad, de stu simple existir y luce en una nueva esfera de existencia más etérea, más pura. inalcanzable y eterna.

Esta eficacia de la apariencia, con abstracción de lo que los filósofos llamarían su facticiclad, esa calidad noética de sus imágenes, infunde en el ámbito de la experiencia poética, una atmósfera onírica. Poetas y estetas de todos los tiempos han encontrado cierto parentesco entre la poesía, el sueño y los sueños, o mejor entre la poesia y las visiones que pueblan la noche del hombre dormido. $Y$ en efecto, en el estado fisiológico del sueño y en los estados afectivos, e imaginativos que lo acompañan nos sentimos transportados a $0^{-}$ tra esfera de existencia, clue no es sin duda irreal, puesto que la vivimos, pero que no corresponde tampoco a la realidart histórica ni a las contiefones nornales del acontecer ni de la inteligibilicladerge Puccinelli Converson

Simultaneiclades inexplicables, misteriosas transposiciones entre los más distintos planos de la experiencia, metáforas que no son simples analogías entre las imágines sino modos de vida; y todo ello envuelto, impregnado en el sentimiento de su transrealidad, es decir en un sentimiento que al par que vive estas apariencias como algo interno y profunclo - a veces con intensísima angustia- las proyecta en el espacio misterioso de la noche como un espectáculo lleno de mágico atractivo. Con lo cual, los sueños como la poesía o ia poesía igual que el sueño o los steños, nos llevan a tuna región donde las distancias, las resistencias y las posibilida- 
des de la vida se transfiguran en el resplandor nocturno del aparecer. Y así, escribe Dilthey, caracterizando la fantasía poćtica y refiriéndose al sueño como su manifestación inicial: "Gracias a la acción de la fantasía, levántase un nuevo mundo, distinto del mundo de la actividad utilfaria, y su fuerza de configuración manifiéstase de modo involuntario en las imágenes del sueño, que es el más antiguo de todos los poctas". ( I).

Algunas breves referencias a la estética de la poesía, en relación con las ideas sobre el sueño $y$ los sueños servirín para poner en claro nuestro punto de vista.

Recogiendo, sin duda, ideas más antiguas, inspiradas en la intuición popular y en la experiencia artística y conectadas con profundas corrientes del sentimiento religioso $y$ del anhelo místico en Grecia, Platón distinguía en el Fedro, cuatro clases de delirio divino según los dioses que lo inspiran, atribuyendo la inspiración profética a Apolo, la de los iniciados a Dionisos, la de los poetas a las Musas y en fin la de los amantes ${ }^{\top}$ a Afroditan ylla Erose Con ello reconoce que la poesía es un transporte en que el alma, más allá de la normal regularidad de la existencia, vive en un mundo de visiones incorpóreas, cle ilusiones, de sueños. Al mismo tiempo, al considerar el delirio como su origen común, establece el parentesco profundo entre estos cuatro modos de comportarse el alma ante la imagen. $Y$ de esta suerte, por último, asienta la doctrina de que la poesía, como la mántica, al par que trasciende la inmediata y corpórea realidad del mundo circundante, nos entrega un mensaje de profundidad y encierra un sentido de misteriosa identificación del alma con

(1) Das Erlebnis und die Dichtung, Leipzig, 1929, piig. 185. 
las fuerzas creadoras de la vida y con lá oscura fatalidad icl destino.

Para venir a los tiempos modernos, pasanclo por el mundo de visiones oniricas legendarias y poeticas en que atbunda la fantasia medioeval, observaremos que las más grandes creaciones de Shakespeare pasan en una atmosfera de sueño, que lejos de contrarlecir el profundo sentido de realiclad que poseía el poeta les confiere st trascenclencia, su pocler, st significación nunversal. Hamlet, Macbeth, Ofelia son figuras poéticas en el más absoluto senticlo de la palabra, porcue más allá đe su realiclad o irrealidad histórica, fáctica, tienen en su propia fulgurante apariencia, stu verdad.

Pero si, por modo general, estéticos y poetas han pensado y sentido la poesía como una transposición de la experiencia a un nutevo platno de la realidad, definible clentro de la categoría vital del sueño, fueron sin duclá los poetas y pensadores del romanticismo allemán quienes con mayor intensidad realizaron, comprendicton y explicaron esa transposición. El sueño (Tranme, rôve), según ellos, es la inmersión del alma en la oscura región donde lá propia vida y la vida universal Je ge identificanl yconfunclen. Las visiones del sueño son las presencias simbólicas en que se conirigura esa abisal iclentidad, y sus analogías, sus incomprensibles analgamals y metamorfosis, la expresión cle la contintidad crcaciora de la actividad de animación nniversal a la vez cósmica y humana. Y la poesía no es sino la expresión rítmica y melódica de la maravillosa realidad del mundo onírico.

Más cerca de nosotros, en la estética de Federico Nietzsche, se afirma este parentesco -y si se quiere esta identidad entre sueño y poesía- en forma llena de significación. Primeramente, al contraponer lo que él llama espíritu apoíneo y espíritu clionisíaco, asinilándolos respectivamente, al sucño y la embriaguez, Nictzsche asienta que todas las for- 
mas de la plástica, y entre ellas las de la poesía épica, pertenecen al mundo del sueño, mundo en que el artista y el poeta, emergiendo del dolor y del frenesí de la oscura voluntad dionisíaca, se calman y encantan contemplando una teoría de fúlgidas y armoniosas imágenes.

Por otra parte, Nietzche considera la música como la forma de arte en que se expresa directamente la oscura voluntad metafísica de la vida, y piensa que la poesía lírica, incluida en la esfera de la música y en que también se exhala la trágica profundidad de la existencia, es de naturalera contraria a la épica. Pero en el fondo, si la poesía lírica evoca imágenes, éstas, al igual que las figuras de la épica, se dan, según la propia comparación del filósofo, cual condensaciones del humo de la embriaguez; y así unas y otras son imágenes de sueño y expanden una como claridad errátil sobre la oscuridad primordial de la embriaguez y de la música.

En su hermosísimo libro "L'Ame Romantique et le Rêve", (Paris I937) Albert Béguin, después de estudiar de modo minucioso y profundo las doctrinas poéticas del romanticismo alemán, analiza otra escuelas afines a él y que van desde Rousseau y Senancour hasta Proust y el suprarrealismo, deteniéndose en las tendencias poéticas representadas por Gerard de Nerval, Víctor Hugo, Baudelaire, Mallarmé y Rimbaud; y cn todas ellas, con mayor o menor intensidad, se encuentra ese carácter misterioso clel objeto poétic que consiste en lucir mas allá del mundo, en el sueño, y en brotar sin embargo de la más oscura y recóndita región metafísica del alma.

Bergson, considera la vigilia como un estado de adecuación entre la memoria y las solicitaciones de la acción, estado en que la memoria proyecta sobre el plano del presente los recuerdos oportunos, los que convienen a la situación 


\section{$-286-$}

de hecho que la vida plantea a nuestra actividad. El sueño, en cambio, es un estado en que la tensión entre la memoria y el presente que es el plano de la acción, se afloja permitiendo a la memoria actualizar un número indeterminado de espontáneos y de libres recuerdos, y lo que es más, de imágines sin relación aparente con lo ya visto y vivido. $Y$ así, dentro de esta doctrina el arte, y en especial la poesía, i no sería el gran sueño que por encima de la acción utilitaria, proyecta ante la mirada del alma sus mil radiantes y cambiantes imágenes. El "détachement" de la vida de que habla Bergson en "Le Rire" ¿qué otra cosa es por relación a la apariencia sino su transposición a un plano en que se clarifica y depura de su contaminación con la práctica y en que luce con toda la nlenitud de su irreductible individualidad? ¿Y qué es ese "détachement" en cuanto al artista sino un modo de ver la apariencia que por su autonomía de las solicitaciones apremiantes de la acción puede compararse al sueño? En el fondo, el realismo estético de Bergson implica una visión directa de la imagen y esta visión directa dela imagen sólo se obtiene por un medioque constituye anctérmino de enlace entre el sueño y el arte a saber: la liberación del mecanismo utilitario, de los esquemas inánimes y abstractos de la acción.

Según Klages, la característica fundamental del mundo de los sueños es la incorporeidad o mejor, la extra-corporeidad de sus visiones, calidad que, por una parte implica su independencia de la mera sensación y determina la ausencia del dolor físico en el sueño y que, por otra parte, hace que el espectáculo onírico no esté sometido al imperio de las que podríamos llamar leyes geométricas del espacio ni a la relación lineal de ahora y ayer que caracteriza la sucesión temporal. En el sueño, como en algunos incomparables paisajes de los pintores chinos, se diría que todo es lejano, aunque no lo es propiamente, ya que en él no existe la definida ten- 
sión polar entre lo distante y lo próximo que es propia del espacio sensible. De nada podría decirse tampoco que es cercano con la palpable y aprehensible proximidad que se da en la vigilia.

El espacio y el tiempo de los sueños son pues un espacio y un tiempo en que, estando abolidas las leyes de las relaciones posicionales de los cuerpos y la relación lineal del acontecer, lo distante y lo próximo, lo simultáneo y lo sucesivo se dan según modos intraducibles en el lenguaje conceptual, corpóreo de la conciencia despierta. No nos encontramos ya en el fluir del tiempo, en el cual cada ahora se vuelve inconteniblemente un ayer, sino en un continuo presente, con infinitos y movibles ahoras, y no estamos tampoco en un espacio exterior que para ser atravesado requiere tiempo, sino en un ilimitado, movible aquí. "La esencia del espacio sensible como la del tiempo sensible estriba en la polaridad de lo próximo y lo lejano. Sustituyéndolos por un ilimitado movible ahora habremos despojado de realidad así lo lejano y lo próximo como el movimiento que los une a entrambos, en el cuerpo de un espació fantasma. Elespaciodel sueño, el fasma del espacio sens̄ible, carece pörla labilidad de su ahora y de su aquí, de la controposición de lo lejano y de lo próximo, y de este modo representa, más bien, el fasma del presente". (I).

Creo que podría resumirse la concepción de Klages sobre la naturaleza del mundo de los sueños diciendo que en él las apariencias son autónomas por relación al mundo sensorial y que una como misteriosa ubicuidad del alma llena el espacio y el tiempo oníricos. Calidad de los sueños que, entre otras, constituye una evidente analogía con el mundo poético y mítico. También aquí, el alma suprime las distan-

(1) Der Geist als Widersacher der Seele, Leipzig 1932. pág. 995. 
cias y transtrueca la situación espacial y temporal de los sucesos. La botas de las siete leguas podrían ser, entre otras mil expresiones, folklóricas, míticas y poéticas, los símbolos de la ubicuidad del alma y de lo que Klages llama labilidad del aquí onírico. Las visiones míticas sobre el tiempo son ejemplos del ahora movible de los sueños. Así, el hombre que sueña al igual que el poeta, vive en la más remota e inexpresable profundidad del espacio y del tiempo como en un misterioso e inexpresable aquí y ahora.

Hay una lejanía en el espacio poético, y el poeta tiene el sentimiento de su absoluta inaprehensibilidad pero aun así el poeta vive en esa lejanía inaprehensible, y la ansiedad, la melancolía, la nostalgia de su emoción se alimentan en una doble fuente: en la visión de lo lejano, que aparece como una esfera de existencia inasequible y absoluta y en el amor a esa lejanía, que aboliendo la distancia forja el sueño del retorno y une al aquí del anhelo el más allá del remoto horizonte.

\section{Biblioteca de Letras}

Hemos hecho tofas estas referencias no tanto para demostrar el parentesco entre la poesía y el sueño, cuanto para deducir de ese parentesco lo que llamamos transrealidad del objeto poético, palabra que designa un cierto modo de ser de la apariencia, que se independiza de las limitaciones espaciales y temporales de la corporeidad y de la acción, pero que no debe tomarse como sinónima de insignificancia, vanidad o irrealidad del objeto poético, puesto que su transrealidad le confiere, al contrario, un misterioso e inexpresable coeficiente de profundidad y de sentido. En el lenguaje popular de Cajamárca —en que se conserva el oro del viejo fondo español - cuando se quiere aludir a la calidad espiritual y poética del aroma se dice que trasciende. Con ello se 
expresa de manera admirable y llena de sentido y de encanto que el objeto aromático sale de sí, abandona su corporeidad e irradia la magia de su apariencia odorante, como una canción o como un poema, en el espacio del sueño y del alma.

Hay diversos planos en la apariencia, planos que se suceden desde el mero contacto sensible - auditivo, visual - con el objeto poético, hasta el oscuro fundamento ontológico de la aparición. La estructura de colores o sonidos que es en sí misma una imagen, evoca otra imagen - que llamaremos significada- la cual despierta acaso una nueva apariencia, y así en número indeterminado hasta el fondo primitivo e inefable. Es como si asistiéramos a una serie de refracciones de la apariencia a través de zoṇas cada vez más profundas del alma, o como si proyectáramos el objeto poético transfigurándolo en término de una creciente lejanía y significación. De donde resulta una tensión entre la apariencia y la profundidad, tensión en que a veces se diría que la apariencia - ya podemos llamarla expresión- es aspirada por la profundiclad de donde emerge, y otras que la apariencia atrae hacia síla profundidad y como que la desvanece $y$ anula en la radiante claridad de sutransparencia.

Es difícil dar ejemplos, de evidencia objetiva, de esta tensión en el campo concreto de la experiencia poética, porque en ella, tanto el sentimiento de la apariencia como el de la profundidad dependen en gran parte de la intervencion de elementos subjetivos. La profundidad, tanto como la apariencia, existen objetivamente pero no todos las perciben. Unos sólo perciben la apariencia y carecen de la intuición de la profundidad. Otros olvidan la apariencia para concentrar su atención en un cierto sentido intelectual que descubren en ella. Hay en fin muchos que no perciben ni la apariencia poética ni su profundidad.

Hay estrofas de San Juan de la Cruz que no obstante la 
clara melodía de sus imágenes, parecen aspiradas, atraídas por la profundidad. Se siente que no todo el contenido de la emoción inspiradora del artista se declara en ellas. Se ve que las palabras y figuras más bien aluden que propiamente expresan. Como si algo invisible en la inmediata aparición de las imágenes, las envolviera y transportara a otra esfera de realidad y de vida.

En cambio los versos de Fray Luis de León tienen una perfecta transparencia. No porque no exista en ellos la profundidad, sino porque ella es como una onda de silencio o de sombra que viniera a expirar en la clara armonía de la superficie. Como ilustración de este concepto merece citarse, entre otras, la famosa composición dedicada a don Francisco de Salinas, y en la cual el poeta hace de la música audible algo así como una figura o un grado para llegar a otra música que se oye de otro modo y que, así mismo, conduce el alma a un como anegamiento místico, extraño a todo lo accidental y perecedero.

$Y$ he aquí como la imagen de la cítara, en este poema, puede servir a nuestrotintento de definir, descle el punto de vista de su transrealidad da calidad del objeto poético. La cítara de que habla Fray Luis de León no es una cítara material, no la pulsa ninguna mano palpable y visible. Con ella quiso aludir el poeta, traduciendo alguna reminiscencia neopatónica al orden perfecto de las esferas siderales y, mejor aun, a la armonía suprasensible, al orden inefable de las esencias ideales. Pero al pronunciar la palabra cítara, creó la realidad de la imagen, en el espacio de la poesía. Y de este modo el alma

Ve cómo el gran maestro

A aquesta inmensa cítara aplicado,

Con movimiento diestro, 
Produce el son sagrado,

Con que este eterno templo es sustentado.

En el lenguaje de la prosa, entre la apariencia y el significado hay un enlace meramente convencional, como el que existe entre los signos algebraicos y las relaciones numéricas o entre las señales verdes o rojas de los semáforos y la continuación o detención del tránsito. Este enlace es de tal naturaleza que pueden cambiarse los signos sin que ello altere en lo más mínimo el modo de ser de las entidades o de las relaciones que en ellos se hacen visibles. En la poesía en cambio, el sentido es inherente a la apariencia, de tal manera que tal sentido sólo en tal apariencia puede configurarse y anarecer. Por eso. toda ver. que la prosa no puede ser el lenguaje expresivo de la poesía, en sentido poético no puede configurarse en términos abst̄ractos. $Y$ bien, a esta indefinible relación entre la apariencia $v$ el sentido en el objeto poético la llamamos transrealidad, palabra que expresa, junto con la autonomía de la apariencia por relación al destino pragmático de la percepción, su calidad de manifestación, revelación, aparición de la profundidad ontológica de lo real.

$Y$ así nos explicamos que la poesía no sea tan sólo aque1la rara esencia que contiene el poema - por más que acaso sea éste la forma más adecuada a tan sutil materia- sino que, en cierto modo sea coextensiva con lo real, y que para gustarla baste con desprender la apariencia de los mecanismos abstractos en que se desvirtúa y pierde para mirarla en la trascendencia de su profundidad y de su luz.

\section{Mariano Iberico.}

